\title{
Coarctation of the aorta corrected during childhood. Clinical aspects during follow-up
}

\author{
Margarida Maria da Costa Smith Maia, Vera Demarchi Aiello, Miguel Barbero-Marcial, M unir Ebaid
}

São Paulo, SP - Brazil

\begin{abstract}
Coarctation of the aorta was first corrected by Clarence Crafoord in 1944 in Sweden, when the area of coarctation was resected and an end-to-end anastomosis was performed in the aorta ${ }^{1}$. Since then, several surgical techniques have been developed aiming to correct the lesion, to normalize the level of systemic blood pressure, to prolong survival and to reduce the prevalence of residual or recurrent coarctation, which was significant at the time end-to-end anastomosis was performed. Among these techniques, isthmusplasty with or without a patch is included ${ }^{2,3}$. Later on, the left subclavian artery was used as a graft, associated or not with the resection of the area of coarctation. This technique was called isthmusplasty with subclavian flap and it aimed to correct coarctations of the aorta when the anatomy was not adequate for the performance of end-to-end anastomosis, thus reducing the incidence of residual coarctation ${ }^{4}$. Mendonça et al ${ }^{5}$ resectioned the left subclavian artery opening it longitudinally on its distal portion and reimplanted the artery in the area of coarctation, thus correcting the narrowed segment and preserving the flow to the left arm.
\end{abstract}

More recently, Dietl and Torres ${ }^{6}$, after exeresis of the area of coarctation, associated the end-to-end anastomosis with widening of the aortic isthmus with the use of a flap of the left subclavian artery or its implantation at the site of the anastomosis. They considered the resection of the area of coarctation and the increase in the area of the anastomosis essential in small children in order to avoid a recurrence of coarctation.

Changes in the end-to-end technique have been introduced aiming to widen the hypoplastic aortic arch and decrease the recurrence of coarctation in children operated upon during the first year of life.

Extensive end-to-end anastomosis in the aortic arch consists of a long incision performed at the low segment of the isthmus and the aortic arch, which is subsequently anastomosed to the oblique incision in the distal aorta, resulting in a wide anastomosis ${ }^{7,8}$.

Instituto do Coração do Hospital das Clínicas - FMUSP

Mailing address: Margarida M.C. Smith Maia - Av. Alfredo Balena 190/4070 Depto de Clínica Médica - 30130-100 - Belo Horizonte, MG - Brazil
Follow-up of patients operated upon according to different techniques has shown a variable incidence of either recoarctation, systemic hypertension or both. Among the factors that contribute to the occurrence of recoarctation are: age at which surgery is performed the younger the child is (especially below six months), the greater the possibility of residual or recurrent coarctation and the lesser the probability of systemic hypertension. ${ }^{9-12}$.

When surgery is performed at older ages, the chances of success at late follow-up decrease and the rate of survival is lower due to the development of cardiovascular complications and a higher incidence of systemic hypertension (19.9\% to $68 \%$ ) when compared with that in the general population ${ }^{11-15}$. Even when surgery is performed in the neonatal period, the probability of developing hypertension later on is about $10 \%$ higher than it is in the normal population ${ }^{11}$. Brouwer et al ${ }^{16}$ considered a low weight at the time of surgery as a more important risk factor for the recurrence of $\mathrm{co}-$ arctation than the age at which the child undergoes surgery. Other factors, such as the technique used, the criteria used in the definition of recurrent coarctation, the morphology of the lesion and the time of follow-up after surgery are also important.

The best technique for the correction of the anomaly has been debated and data are controversial when different techniques, such as end-to-end anastomosis and isthmusplasty with subclavian flap are compared. Some authors ${ }^{10,17-19}$ suggest the use of isthmusplasty with subclavian flap in the first months of life because it provides a lower incidence of recurrent coarctation ( $4 \%$ to $7 \%$ ) when compared with the end-to-end anastomosis technique ( $38 \%$ to $42 \%$ ). However, others ${ }^{9,20}$ do not find any advantages to isthmusplasty with subclavian flap in terms of mortality or prevalence of recoarctation when it is compared with the end-to-end anastomosis technique, considering that the former has the disadvantage of the possibility of late narrowing of the isthmus tissue with consequent sequelea to the left arm. Beekman et $\mathrm{al}^{21}$ in a study of both techniques in 125 patients who underwent surgery under one year of age noticed that the risk of re-operation in 10 years was about the same for both techniques. Although Knott-Craig et al ${ }^{22}$ noticed a similar incidence of recurrent coarctation in neonates in whom the end-to-end anastomosis technique was used (16\%) and in those in whom an isthmusplasty with subclavian flap was 
performed (13\%), Messmer et al ${ }^{23}$, in a series of 53 infants under one year of age, showed a good surgical result both with the end-to-end anastomosis technique and the isthmusplasty with subclavian flap, with the prevalence of recoarctation ranging from 0 to $9 \%$, respectively. In a recent study that we performed ${ }^{24}$, no statistical difference occurred between the prevalence of recoarctation among patients who underwent the end-to-end anastomosis technique and isthmusplasty with subclavian flap and whose ages ranged from 0 to 14 years. Messmer et $\mathrm{al}^{23}$ also noticed that patients who underwent the aortoplasty technique with the use of a patch or the Mendonça technique had a high incidence of recurrent coarctation $42 \%$ and $43 \%$ respectively. These high figures were thought to be caused by a more severe form of the anomaly when the first technique was used and by a massive residual concentric thickening of the aortic wall and dislodgment of the left subclavian artery in the second technique. In this series, age at surgery was not a risk factor for recurrence of coarctation, and it was concluded that the surgical results of correction of coarctation of the aorta in the first year of life depend more on the anatomical features peculiar to the anomaly, which greatly determine the technique to be used, than to the technique itself.

Isthmusplasty with the use of a patch is associated with a high prevalence of recurrent coarctation $(21 \%$ to $47 \%$ ), especially when surgery is performed in the neonatal period or in the first year of life ${ }^{22,25,26}$.

Surgical mortality - In-hospital mortality in coarctation of the aorta varies according to the age at which surgery is performed and to the association of other complex cardiac defects. Different surgical techniques do not seem to influence mortality $10,22,23,26$. When patients are operated upon in the neonatal period, in hospital mortality ranges from 0 to $14.4 \%$ for isolated coarctation, and from $15.2 \%$ to $25 \%$ for coarctation associated with complex heart diseases ${ }^{19,22,27}$. When children operated upon during the first year of life are considered, mortality ranges from 0 to $29 \%$ for isolated coarctation, and from $7.5 \%$ to $58 \%$ for coarctation associated with complex heart diseases $9,18,23,28-30$.

Recoarctation - The concept of recoarctation is controversial and the ideal method for identifying it is also debatable. Recoarctation is considered to be present whenever the rest gradient at the stenosis in the anastomosis is higher than $20 \mathrm{mmHg}$. More precisely, residual coarctation is defined by the presence of a gradient in the operated area in the early post-operative period when the patient is still in the hospital, but is defined by recurrent coarctation when it is detected after hospital discharge ${ }^{16,31,32}$. A peak gradient at rest greater than $20 \mathrm{mmHg}$ through the area of coarctation is the most used measurement for the detection of residual or recurrent coarctation 12,19,25,27,32-34 . However, no consensus exists about that, and gradients ranging from 10 to $30 \mathrm{mmHg}$ have also been used as reference point ${ }^{18,35-37}$. Even if this parameter were accepted by all, some controversy would still exist, because the systolic gradient has been determined by different methods in several studies in the literature, such as: simultaneous measurement of the blood pressure in the superior and inferior limbs with a sphygmomanometer, instantaneous peak gradient by Doppler echocardiography or direct measurement by cardiac catheterization ${ }^{12,32-34,38}$. In addition, the development of collateral circulation also remains after surgery and may decrease the validation of the systolic gradient when it is used in isolation. Some surgical series ${ }^{9,20}$ have used the ratio between patients who underwent a second intervention for recurrent coarctation and those free of a second procedure as a criterion for the absence of recurrent coarctation. This is not appropriate and may underestimate or overestimate the prevalence of residual or recurrent coarctation ${ }^{31}$. Kirklin and Barrat-Boyes ${ }^{31}$ believe that the diagnosis of recurrent coarctation can only be established with some accuracy through the use of an imaging method or the examination of the operated area. The lack of accuracy in defining the preoperative severity of the coarctation, in the definition of the degree of residual or recurrent lesions and in the establishment of the most reliable diagnostic method to measure it, make the follow-up of these patients and the comparison of different surgical techniques a complex task ${ }^{38}$. Another factor that complicates postoperative evaluation of coarctation of the aorta is the fact that it is not known how often recurrent coarctation is not a real residual lesion, because, although recurrence may develop, its detection by serial angiography or by other methods is infrequent ${ }^{31}$. In addition to the technical surgical problems involved, the hypoplastic segment between the common carotid artery and the left subclavian artery may contribute to the residual gradient. Some authors ${ }^{39}$ believe that when hypoplasia of the aortic arch associated with coarctation occurs, reconstruction of the whole aortic arch is mandatory to decrease surgical mortality and the prevalence of recurrent coarctation, especially when associated complex intracardiac lesions or left ventricular dysfunction are present. Others ${ }^{40-42}$ have demonstrated in well controlled studies in infants, who were operated upon using end-to-end anastomosis or isthmusplasty with subclavian flap, that a significant increase occurs in the hypoplastic aortic arch and that this increase is greater in patients operated upon in the first month of life. They suggest that reconstruction of the aortic arch in these cases is unnecessary. The late evolution in these patients has not been established, nor has the behavior of the hypoplastic aortic arch, when older children are operated upon. It is important to note that recurrent coarctation, both in children and in adults, is more common when the anatomy of the coarctation is not adequate for an end-toend anastomosis due to a segmental stenosis or the presence of an aneurysm on the aorta. ${ }^{31,32}$. Taking all these factors into consideration, it is not surprising that such a variability in the prevalence of recurrent coarctation exists (5\% to 60\%); however, these figures have progressively decreased in more recent series ${ }^{10,12,16,27,30,33,35}$.

Recoarctation is difficult to diagnose, especially in children, in whom measuring blood pressure is not always easy. 
In our recent study ${ }^{24}$, none of the noninvasive diagnostic methods (Doppler echocardiogram or MRI), when used in isolation, detected all cases of re-coarctation. Differences occurred in the gradients obtained by Doppler and by cardiac catheterization. This may be explained in part by the high sensitivity of the first method and by the presence of different degrees of hypoplasia of the aortic arch, since both of them can increase the gradient diagnosed by continuous wave Doppler. In addition, the instantaneous gradient obtained by Doppler echocardiography using the simplified Bernoulli equation and the maximal velocity at the area of coarctation is not always accurate due to several conditions. The simplified Bernoulli equation considers the proximal velocity to the obstruction to be negligible. This is reasonable for severe stenosis $(>75 \%)$, and in mild stenosis the error can be corrected by considering the proximal velocity. However, exclusion of the proximal velocity in calculating the gradient by Doppler may overestimate it, especially when the gradient is small ${ }^{43}$. The proximal velocity to the coarctation may also be elevated due to high flow in the ascending aorta or high cardiac output ${ }^{44}$. However, other conditions are assumed to be present in the simplified Bernoulli equation, and, even when this is not so, they cannot be easily corrected. It is assumed that the pressure distal to the stenosis remains constant, which is true only for severe stenoses. In stenoses less than $75 \%$, some pressure recovery occurs after the stenosis ${ }^{45}$. The Bernoulli equation does not take this pressure recovery into consideration and therefore overestimates the severity of stenoses of mild degree ${ }^{43,46,47}$.

Experiments ${ }^{45}$ have shown that in mild constrictions the pressure gradients can be overestimated by as much as $30 \%$ and in more severe stenoses turbulent flow occurs after the stenosis causing loss of pressure. Again Bernoulli equation does not consider this secondary loss of pressure and therefore underestimates the severity of important stenosis $^{48}$.

Theory as well as experiments ${ }^{47}$ indicate that the coefficient of loss of the equation $(\mathrm{K})$, usually considered as a constant value of 4.0 is in fact related to the severity of the lesion. The type of stenosis is also a factor that can contribute to errors in calculating the pressure gradient when the simplified Bernoulli equation is used ${ }^{48}$.

Oshinski et $\mathrm{al}^{47}$ in an in vivo and in vitro study concluded that in mild stenosis, the $\mathrm{K}$ loss coefficient is less than 4.0 and that in severe stenosis $\mathrm{K}$ is higher than 4.0. Data from the literature are controversial in terms of the degree of correlation between the peak instantaneous gradient obtained by Doppler echocardiogram and the peakto-peak gradient obtained by cardiac catheterization. However, several authors ${ }^{46,49,50}$ have shown that the peak instantaneous gradient by Doppler is higher than the gradient obtained by cardiac catheterization and by sphygmomanometer in patients with coarctation of the aorta.

Although the Doppler-measured gradient is an important method in the early and late post-operative evaluation of coarctation of the aorta, it has some limitations in patients with less severe forms of stenosis, in the presence of high cardiac output, in patients with systemic hypertension or aortic regurgitation, in the presence of ascending aortic dilation, as well as in patients with tortuous segments or stenoses in other areas besides the site of anastomosis.

In addition to this, it has also been observed in six patients who underwent surgery ${ }^{51}$ that the whole aortic arch was hypoplastic with a local systolic gradient. Hypopolasia of the distal transversal aortic arch and of the isthmus in coarctation of the aorta has also been observed in fetal ultrasound in isolated coarctation of the aorta and also when it is associated with other cardiac defects ${ }^{52,53}$. In a recent study ${ }^{24}$, we showed that hypoplasia of the aortic arch in operated coarctation of the aorta is not rare when it is associated with other cardiac anomalies and that a significant gradient can exist in the hypoplastic aortic arch with or without recoarctation.

To differentiate recoarctation from a hypoplastic aortic arch is not easy, because both entities have similar clinical presentations. It seems clear that true recoarctation is much rarer and that hypoplasia of the aortic arch also contributes to the aortic gradient in the postoperative period ${ }^{24,51,54}$. The presence of hypoplasia of the aortic arch in the postoperative period of coarctation suggests that primary abnormalities of the aortic wall can exist that limit its growth and elasticity, as can a greater percentage of collagen than of smooth muscle, as observed by some authors ${ }^{55,56}$. At the same time, these abnormalities predispose the aorta to the development of dilations and aneurysms.

The use of MRI has shown to be a very important in the study of operated coarctation of the aorta due to the great resolution and the sharpness of the images obtained in different views and also to the high correlation between images and measurements obtained by cardiac catheterization $^{57-59}$. In addition to this, radiation or ionizing contrast are not used with MRI. However, the time required to perform the examination - approximately 30 minutes - the high cost and the necessity to use general anesthesia in children under six years of age limit its use in the routine evaluation of these patients. Another problem is that, in some cases, it is not possible to visualize the whole aorta in only one section. MRI is an effective method for evaluating the anatomical results after surgery for coarctation of the aorta, and it spares the patient having to have repeated cardiac catheterizations ${ }^{60}$. Some authors ${ }^{61}$ recommend that all operated patients should undergo an MRI every five years when symptoms exist or when other methods have identified any complications. In a recent study by Oshinski et $\mathrm{al}^{47} \mathrm{it}$ is suggested that MRI be used as a complete diagnostic method in the evaluation of coarctation of the aorta, because with MRI the severity, site and the gradient at the stenosis can be established with confidence.

The incidence of recoarctation reported by several authors according to different surgical techniques is variable, depending on age and weight at the time of surgery and on the duration of follow-up. In our recent study ${ }^{24}$, no statistical difference occurred in the distribution of patients with recoarctation according to age at the time of surgery. 
This is not in agreement with other authors ${ }^{10,12,62}$, who consider that recoarctation is more frequent in patients operated upon during the first year of life, especially in the first six months. However, others ${ }^{23,63}$ have not found any relationship between age at the time of surgery and recoarctation. More recently, some authors ${ }^{30}$ have concluded that elective surgery for coarctation of the aorta can be performed with a low probability of recoarctation $(5 \%)$ in the first year of life, if the neonatal period is excluded. In Brazil, Barbero-Marcial et al ${ }^{64}$ reported a $5.9 \%$ incidence of recoarctation in 17 patients operated upon in the first year of life who were followed for seven years. The progressive decrease in the incidence of recoarctation in patients operated upon in the first year of life may be due to an improvement in surgical techniques and in the type of suture that has been developed in recent years, as well as greater experience in performing surgeries.

The reasons why recoarctation develops are not well understood and several factors seem to be related to it: small patch, inadequate growth of the aorta at the line of suture of the anastomosis, nonresection of the peri-ductal tissue and of the crista that continue to involve and obliterate the aortic lumen ${ }^{18,20}$, proliferation of the anomalous mesodermic tissue, which causes significant medial and intimal proliferation of the artery and constriction of the nonexcised ductal tissue ${ }^{65-67}$. In addition to this, some authors ${ }^{68}$ consider that a rapid recurrence of coarctation of the aorta may be due to thrombi in the line of the suture. Technical factors are also responsible for recoarctation, such as insufficient resection of a hypoplastic aortic segment followed by an end-to-end anastomosis or excessive tension on the suture line due to inadequate mobilization of the aorta above and below the coarctation.

Other technical causes are: inadequate modeling of the Dacron patch or of the subclavian artery, grafting of a small tube or its kinking, residual hypoplastic segment of the aortic arch, usually between the common carotid and the left subclavian arteries, and tubular hypoplasia ${ }^{31}$. In addition to these factors, incomplete correction of associated cardiac lesions helps maintain hypoplasia of the aortic arch.

Treatment of these complications can be performed by balloon angioplasty, as well as by some recent and promising techniques that have been incorporated into the treatment of hypoplasia of the aortic arch and recoarctation, such as placement of an expandable stent that can stretch as the child grows ${ }^{69,70}$.

Systemic arterial hypertension-Correction of the coarctation of the aorta decreases the prevalence of late hypertension, as reported in several studies in the literature, ranging from $11 \%$ to $68 \%$, according to the studied range of age, time of follow-up and the criteria used for the definition of systemic arterial hypertension, which complicates the comparison of different existing studies ${ }^{14,29}$. Clarkson et al ${ }^{63}$ observed that the frequency of hypertension decreased significantly between one and two years after surgery and that the majority of patients had normal blood pressure between five and ten years after surgery, which Presbitero et al ${ }^{14}$ also observed. In addition to this, the prevalence of hypertension was significantly greater among patients operated upon after 20 years of age when compared with that of patients operated upon between 5 and 19 years of age. However, after longer periods of follow-up, an increase occurred in the proportion of patients from all ages. Koller et al ${ }^{13}$ studied 362 patients who had been operated upon during the first days of life and as late as 64 years of age and followed these patients for approximately 23 years. They detected a preoperative prevalence of $82.5 \%$ of hypertension against a late follow-up prevalence of $25 \%$. During clinical follow-up, hypertension among patients who had been operated upon before ten years of age decreased even more, but remained constant among older patients. The prevalence of hypertension among patients operated upon between 2 and 9 years was $10.0 \%$, which was significantly lower than that observed in patients operated upon after the age of ten $(30.7 \%)$. In a recent study with a follow-up period after surgery longer than ten years, Amaral et al ${ }^{71}$ observed a $19 \%$ prevalence of hypertension in patients who had surgery during the first year of life and $28 \%$ among patients operated upon after 11 years. In our study ${ }^{24}$, the prevalence of hypertension at rest was $38.24 \%$ in 102 patients who were followed for an average of four years after surgery. No statistical difference occurred among patients of different ages ( 0 to 14 years). Lerberg et al ${ }^{29}$ found prevalence of $23.52 \%$ and $21.15 \%$ of hypertension in patients who had had surgery before one year of age and after ten years of age, respectively. On the other hand, several studies showing a lower prevalence of hypertension, used as a minimal value higher values than those currently accepted as normal for adults and children ${ }^{14,15,72}$. Few studies have been conducted about the behavior of blood pressure in coarctation of the aorta in children below five years of age, and controlled studies are needed.

Causes of systemic hypertension in the late postoperative period of correction of coarctation of the aorta are not well established, and even patients who are normotensive at rest and have no recoarctation may have a hypertensive response during exercise ${ }^{64,73}$.

Several hypotheses have been suggested to explain why hypertension may persist even after a successful correction of the coarctation has been performed.Late correction has been shown to be a risk factor for hypertension ${ }^{35,64,72}$. The surgical technique that was used, recoarctation or significant hypoplasia of the transversal aortic arch, have also been shown to be the cause of late hypertension ${ }^{10,35,74}$. Studies by Gidding et al ${ }^{75}$ suggest that an abnormal reactivity of resistance vessels proximal to the coarctation may occur when vasoconstrictors such as epinephrine are used. More recently, Ross et a ${ }^{76}$ noticed a higher concentration of epinephrine and of serum renin at peak exercise in operated hypertensive patients than in normotensive patients, suggesting that a hypertensive response to exercise in these patients may be the result of peripheral vasoconstriction secondary to the increase of the sympathetic activity and of the serum renin. On the other hand, Simsolo et al ${ }^{73}$, in a study of 
the mechanisms of arterial hypertension in children successfully operated upon for correction of coarctation of the aorta and presenting with essential hypertension, concluded that the hyperactivity of blood pressure after coarctectomy was not related to abnormalities of the autonomous nervous system or to the renin-angiotensin-aldosterone axis.

Late arterial hypertension may be related to baroreceptor dysfunction or to primary abnormalities of the arterial wall. Gardiner et al ${ }^{77}$ detected a decreased response to vasodilators and to distal occlusion and release of the right brachial arteries of normotensive patients who had undergone surgery for correction of the coarctation. Functional abnormalities of central and peripheral vessels are suggested as an explanation. These authors emphasize that an abnormal vascular response was not related to the age at which surgery was performed, being observed even in patients who had had surgery in the neonatal period. Some authors ${ }^{55}$ have detected a higher quantity of collagen than smooth muscle proximal to the area of coarctation in the aorta, as well as less in vitro contractility of these aortic segments in response to epinephrine. They concluded that the pre-coarctation wall of the aorta is stiffer than the wall distal to the coarctation, which may influence baroreceptors on the proximal vessels towards tolerating higher pressures. Recently, these factors have been confirmed by Ong et al. ${ }^{78} \mathrm{Xu}$ et al ${ }^{79}$ have also observed by intravascular ultrasound, associated with arterial pressure measurement by catheterization, that the index of stiffness at the site of coarctation and on its proximal segment was significantly higher than in the distal segment and this was not changed by balloon dilation. It is then suggested that this abnormal stiffness of the segment proximal to the coarctation may contribute to the occurrence of hypertension in these patients. Others ${ }^{77}$ have speculated that the arterial vascular abnormalities found on the proximal precoarctation vessel may be present many years after surgical correction of the coarctation and that these abnormalities may be irreversible. Recently, Machii and Becker ${ }^{56}$ quantified collagen density by microdensitophotometry and the positivity of alpha-actin for the smooth muscle by means of immunohistochemistry. The number of elastin shelves in the transversal aortic arch was high. In addition to this, they also compared their data with those obtained previously in normal aortas and concluded that both the hypoplastic segment and the ascending aorta from specimens with coarctation of the aorta had a higher quantity of collagen than normal specimens. These findings show that late arterial hypertension in operated coarctation of the aorta is the result of a complex interaction between arterial structural factors and physiopathological factors that have not been well elucidated yet and that may persist, independently of correction of the anomaly or the age at which it is performed. It is not simply the result of residual coarctation.

Other complications - Among the late complications of operated coarctation there is a high incidence of aortic aneurysms in patients who undergo aortoplasty with a patch, ranging from $24 \%$ to $38 \%$, according with some authors ${ }^{80,81}$. However, Knyshov et al ${ }^{82}$ detected an incidence of aortic aneurysms of $5.4 \%$ in a series of 891 operated patients, which was predominant in patients in whom an aortoplasty with a patch had been performed. These authors emphasize that aneurysms are more frequently observed in prolonged follow-up. Among the factors that contribute to aneurysm formation are: tension on the aortic wall contralateral to the wall where the patch was placed, which is less compliant; local inflammatory response to the Dacron patch; and persistence of the ductal tissue at the site of the anastomosis, which provides fragile support for the suture and a tissue that is more susceptible to the increase in tension of the aortic wall ${ }^{81,83}$, which favors the development of this complication.

Left ventricular function - Before the seventies, it was not known if infants who presented with decreased left ventricular systolic function secondary to the prolonged pressure overload and who needed early correction of the coarctation of the aorta, would maintain a permanent systolic dysfunction, in spite of successful correction. Graham et al ${ }^{84}$ noticed, in a small number of patients, that systolic function was normal or even increased in patients who had been operated upon for correction of coarctation and who had had systolic dysfunction preoperatively. They then concluded that abnormalities in left ventricular function in children in their first year of life were greatly related to the increased afterload and that they did not indicate a permanent compromise of the contractile left ventricular systolic function. More recently, Krogmann et al ${ }^{85}$ noticed that-both in patients operated upon in the first year of life or later left ventricular systolic function was normal, although infants had severe left ventricular dysfunction before. Both studied groups showed persistence of mild myocardial hypertrophy after correction of the coarctation, which was thought to be the result of the gradient at the site of coarctation during exercise. Other authors ${ }^{78,86-88}$, however, detected a persistent increase in the mass index of the left ventricle and normal systolic and diastolic function only in patients who had had surgery before one year of age, however those who had had surgery later on showed an increase in mass, abnormal diastolic function and increased left ventricular systolic function.

In our study, ${ }^{24}$ some of the patients operated upon at a mean age of $1.23 \pm 1.37$ years and with ventricular contractility below normal $(\mathrm{EF} \leq 0.65)$ had significant improvement in left ventricular contractility. This is clinically relevant, because it has implications for the indication for surgery. In addition to this, it is believed that severe systolic dysfunction occurs only in neonates or in the first months of life ${ }^{84}$. This was not confirmed by this study, in which children above two years of age had severe left ventricular systolic function, which significantly improved after correction of the coarctation and of the associated lesions. Thus, correction of the obstruction is very important, even in older children with left ventricular systolic dysfunction, because left ventricular contractility tends to normalize. Some authors ${ }^{78,87,89}$ noticed persistent hyperkinesis of the left ventricle in patients who had a late surgery, that is, with a mean age older than five years. 
Although treatment of coarctation is relatively simple and early results are encouraging, a continuous postoperative follow-up of these patients is very important due to the possibility of complications. In addition to this, new comparative studies are necessary to study the evolution curve of the blood pressure of these patients, as well as the behavior of the myocardium and of systolic and diastolic left ventricular function in selected groups.

\section{References}

1. Crafoord C, Nylin G. Congenital coarctation of the aorta and its surgical treatment. J Thorac Surg 1945; 14: 347-61.

2. Vossschulte VK. Isthmusplastik zur Behandlung der Aortenisthmusstenose. Thoraxchirurgie 1957; 4: 443-50.

3. Vossschulte VK. Surgical correction of coarctation of the aorta by an "isthmusplastic" operation. Thorax 1961; 16: 338-45.

4. Waldhausen JA, Nahrwold DL. Repair of coarctation of the aorta with subclavian flap. J Thorac Cardiovasc Surg 1966; 51: 532-3.

5. Mendonça JT, Carvalho MR, Costa RK, Filho EF. Coarctation of the aorta: a new surgical technique. J Thorac Cardiovasc Surg 1985; 90: 445-7.

6. DietlCA, Torres AR. Coarctation of the aorta: anastomotic enlargement with subclavian artery two new surgical options. Ann Thorac Surg 1987; 43: 224-5.

7. Zannini L, Lecompte Y, Galli R, et al. La coartazione aortica con ipoplasia dell' arco: descrizione di una nuova tecnica chirurgica. G Ital Cardiol 1985; 15: 1045-8.

8. Lansman S, Shapiro J, Schiller MS, et al. Extended aortic arch anastomosis for repair of coarctation in infancy. Circulation 1986; 74(suppl): I-37-41.

9. Van Son JAM, Daniëls O, Vincent JG, Van Lier HJJ, Lacquet LK. Appraisal of resection and end-to-end anastomosis for repair of coarctation of the aorta in infancy: preference for resection. Ann Thorac Surg 1989; 48: 496-502.

10. Sciolaro C, Copeland J, Cork R, Barkenbush M, Donnerstein R, Goldberg S. Longterm follow-up comparing subclavian flap angioplasty to resection with modified oblique end-to-end anastomosis. Thorac Cardiovasc Surg 1991; 101: 1-13.

11. Brouwer MHJ, Erasmus ME, Ebels T, Eijgelaar A. Influence of age on late survival, late hypertension, and recoarctation in elective aortic coarctation repair. J Thorac. Cardiovasc Surg 1994; 108: 525-31.

12. Kappetein AP, Zwinderman AH, Bogers AJJC, Rohmer J, Huysmans H.A. More than thirty-five years of coarctation repair an unexpected high relapse rate. J Thorac Cardiovasc Surg 1994; 107: 87-95.

13. Koller M, Rothlin M, Senning A. Coarctation of the aorta: review of 362 operated patients. Long-term follow-up and assessment of prognostic variables. Eur Heart J 1987; 8: 670-9.

14. Presbitero P, Demarie D, Villani M, et al. Long-term results (15-30 years) of surgical repair of aortic coarctation. Br Heart J 1987; 57: 462-7.

15. Cohen M, Fuster V, Steele PM, Driscoll D, McGoon DC. Coarctation of the aorta long-term follow-up and prediction of outcome after surgical correction. Circulation 1989; 80: 840-45.

16. Brouwer MHJ, Kuntze EE, Ebels T, Talsma MD, Eijgelaar A. Repair of aortic coarctation in infants. Thorac Cardiovasc Surg 1991; 101: 1093-8.

17. Campbell DB, Waldhausen JA, Pierce WS, Fripp R, Whitman V. Should elective repair of coarctation of the aorta be done in infancy? J Thorac Cardiovasc Surg 1984; 88: 929-38.

18. Penkoske PA, Williams WG, Olley PM, et al. Subclavian arterioplasty. Repair of coarctation of the aortain the first year of life. J. Thorac Cardiovasc Surg 1984; 87: 894-900.

19. Merrill WH, Hoff SJ, Stewart JR, Elkins CC, Graham TP, Bender HW. Operative risk factors and durability of repair of coarctation of the aorta in neonates. Ann Thorac Surg 1994; 58: 399-403.

20. Cobanoglu A, Teply JF, Grunkemeier GL, Sunderland CO, Starr A. Coarctation of the aorta in patients younger than three months. A critique of subclavian flap operation. J Thorac Cardiovasc Surg 1985; 89: 128-35.

21. Beekman RH, Rocchini AP, Behrendt DM, et al. Long-term outcome after repair of coarctation in infancy: subclavian angioplasty does not reduce the need for reoperation. J Am Coll Cardiol 1986; 8: 1406-11.

22. Knott-Craig CJ, Elkins RC, Ward KE, et al. Neonatal coarctation repair. Influence of tecnique on late results. Circulation 1993; 88: 198-204.

23. Messmer BJ, Minale C, MühlerE, Bernuth G. Surgical correction of coarctation in early infancy: does surgical technique influence the result? Ann Thorac Surg 1991; 52: 594-603.

24. Maia MMCS. Estudo evolutivo de crianças submetidas à correção operatória de coarctação de aorta (Tese de Doutorado). São Paulo: Universidade de São Paulo, 1998; 130p.

25. Malan JE, Benatar A, Levin SE. Long-term of coarctation of the aorta repaired by patch angioplasty. Int J Cardiol 1991; 30: 23-32.
26. Quaegebeuer JM, Jonas RA, Weinberg AD, Blackstone EH, Kirklin JW. Outcomes in seriously ill neonates with coarctation of the aorta. A multiinstitutional study. J Thorac Cardiovasc Surg 1994; 108: 841-54.

27. Korbmacher B, Krogmann ON, Schmitt HH, Heusch A, Bourgeois M. Long-term outcome of 110 neonates with critical coarctation. Cardiol Young 1996; 6(suppl): S-39.

28. Bergdahl LAL, Blackstone EH, Kirklin JW, Pacifico AD, Bargeron LMJ. Determinants of early sucess in repair of aortic coarctation in infants. Thorac Cardiovasc Surg 1982; 83: 736-42.

29. Lerberg DB, Hardesty RL, Siewers RD, Zuberbuhler JR, Bahnson HT. Coarctation of the aorta in infants and children: 25 years of experience. Ann Thorac Surg 1982; 33: 159-70.

30. Pfammatter JP, Ziemer G, Kallfelz HC. End-to-end resection for isolated coarctation - comparison of results in neonates and infants. Cardiol Young 1996; 6(suppl): S-36.

31. Kirklin JW, Barratt-Boyes BG. Cardiac Surgery. $2^{\text {nd }}$ ed. New York: Churchill Livingstone 1993. Cap 34: 1263-325.

32. Conte S, Lacour-GayetF, Serraf A, et al. Surgical management of neonatal coarctation. J Thorac Cardiovasc Surg 1995; 109: 663-75.

33. Hartmann A.F, Goldring D, Hernandez A, et al. Recurrent coarctation of aorta after successful repair in infancy. Am J Cardiol 1970; 25: 405-10.

34. Rao SP, Chopra PS, Koscik R, Smith PS, Wilson AD. Surgical versus balloon therapy for aortic coarctation in infants $\leq 3$ months old. J Am Coll Cardiol 1994; 23: 1479-83.

35. Nanton MA, Olley PM. Residual hypertension after coarctectomy in children. Am J Cardiol 1976; 37: 769-72.

36. Kappetein PA, Guit GL, Bogers AJJC, et al. Noninvasive long-term follow-up after coarctation repair. Ann Thorac Surg 1993; 55: 1153-9.

37. Cyran SE, Grzeszczak M, Kaufman K, et al. Aortic "recoarctation" at rest versus at exercise in children as evaluated by stress Doppler echocardiography after a "good"operative result. Am J Cardiol 1993; 71: 963-70.

38. Hanley FL. The various therapeutic approaches to aortic coarctation: is it fair to compare? J Am Coll Cardiol 1996; 27: 471-2.

39. Zannini L, Gargiulo G, Albanese SB, et al. Aortic coarctation with hypoplastic arch in neonates: a spectrum of anatomic lesions requiring different surgical options. Ann Thorac Surg 1993; 56: 288-94.

40. Siewers RD, Ettedgui J, Pahl E, Tallman T, Nido PJ. Coarctation and hypoplasia of the aortic arch: will the arch grow? Ann Thorac Surg 1991; 52: 608-14.

41. Brouwer MHJ, Cromme-Dijkhuis AH, Ebels T, Eijgelaar A. Growth of the hypoplastic aortic arch after simple coarctation resection and end-to-end anastomosis. J Thorac Cardiovasc Surg 1992; 104: 426-33.

42. Myers JL, McConnell BA, Waldhausen JA. Coarctation of the aorta in infants: does the aortic arch grow after repair? Ann Thorac Surg 1992; 54: 869-75.

43. Marx GR, Allen HD. Accuracy and pitfalls of Doppler evaluation of the pressure gradient in aortic coarctation. J Am Coll Cardiol 1986; 7: 1379-85.

44. Hatle L, Angelsen B. Doppler Ultrasound in Cardiology: Physical Principles and Clinical Applications. $2^{\text {nd }}$ ed. Philadelphia: Lea \& Febiger, 1985: 219.

45. Yoganathan AP, Valdes-Cruz LM, Schmidt-Dohna J, et al. Continuous-wave Doppler velocities and gradients across fixed tunnel obstructions: studies in vitro and in vivo. Circulation 1987; 36: 657-66.

46. Houston AB, Simpson IA, Pollock JCS, Jamieson MPG, Doig WB, Coleman EN Doppler ultrasound in the assessment of severity of coarctation of the aorta and interruption of the aortic arch. Br Heart J 1987; 57: 38-43.

47. Oshinski JN, Parks JW, Markou CP, et al. Improved measurement of pressure gradients in aortic coarctation by magnetic resonance imaging. J Am Coll Cardiol 1996; 28: 1818-28.

48. Levine RA,, Jimoh A, Cape EG, McMillan S, Yoganathan AP, Weyman AE. Seminar on in vitro studies of cardiac flow and their applications for clinical Doppler echocardiography - III. J Am Coll Cardiol 1989; 13: 706-15.

49. Chan KC, Dickinson DF, Wharton GA, Gibbs JL. Continuous wave Doppler echocardiography after surgical repair of coarctation of the aorta. Br Heart J 1992; 68: 192-4. 
50. Wendel H, Teien D, Human DG, Nanton MA. Doppler echocardiographic and morphologic evaluation of patients following operative repair of aortic coarctation. Acta Paediatr 1992; 81: 247-52.

51. DeLeon MM, DeLeon SY, Quinones JA, et al. Management of arch hypoplasia after successful coarctation repair. Ann Thorac Surg 1997; 63: 875-80.

52. Morrow WR, Huhta JC, Murphy DJ, McNamara DG. Quantitative morphology of the aortic arch in neonatal coarctation. J Am Coll Cardiol 1986; 8: 616-20.

53. Hornberger LK, Sahn DJ, Kleinman CS, Copel J, Silverman NH. Antenatal diagnosis of coarctation of the aorta: a multicenter experience. J Am Coll Cardiol 1994; $23: 417-23$

54. Pinzon JL, Burrows PE, Beson LN, et al. Repair of coarctation of the aorta in children: postoperative morphology. Radiology 1991; 180: 199-203.

55. Sehested J, Baandrup U, Mikkelsen E. Different reactivity and structure of the prestenotic and poststenotic aorta in human coarctation. Implication for baroreceptor function. Circulation 1982; 65: 1060-5.

56. Machii M, Becker AE. Hypoplastic aortic arch morphology pertinent to growth after surgical correction of aortic coarctation. Ann Thorac Surg 1997; 64: 51620.

57. Filippini LHPM, Beekman RP, Coul BMR, Beek FJA, Hutter PA, Meijboom EJ Follow-up of baloom dilatation for native coarctation. Cardiol Young 1996; 6(suppl): S-36.

58. Parga Filho J, Ávila L, Kajita L, et al. Coarctação da aorta: estudo anátomo-funcional pela ressonância magnética. Rev Soc Cardiol ESP 1997; 7(suppl): 29.

59. Mendelsohn AM, Banerjee A, Donnelly LF, Schawartz DC. Is echocardiography or magnetic resonance imaging superior for precoarctation angioplasty evaluation? Cathet Cardiovasc Diagn 1997; 42: 26-30.

60. Weber HS, Mosher T, Mahraj R, Baylen BG. Magnetic resonance imaging demonstration of "remodeling" of the aorta following balloon angioplasty of discrete native coarctation. Pediatr Cardiol 1996; 17: 184-8.

61. Kilner PJ, Shinohara T, Sampson C, Mohiaddin RH, Firmin DN, Somerville J. Repaired aortic coarctation in adults - magnetic resonance imaging with velocity mapping shows distortions of anatomy and flow. Cardiol Young 1996; 6: 20-7.

62. Patel R, Singh SP, Abrams L, Roberts KD. Coarctation of aorta with special reference to infants: long- term results of operation in 126 cases. Br Heart J 1977; 39: 1246-53.

63. Clarkson PM, Nicholson MR, Barratt-Boyes BG, Neutze JM, Whitlock RM. Results after repair of coarctation of the aorta beyond infancy: a 10 to 20 year followup with particular reference to late systemic hypertension. Am J Cardiol 1983 51: 1481-8

64. Barbero-Marcial M, Verginelli G, Sirera JC, Ebaid M, Zerbini E.J. Surgical treatment of coarctation of the aorta in the first year of life. Immediate and late results in 35 patients. Thorac Cardiovasc Surg 1982; 30: 75-8.

65. Mulder DG, Linde LM. Recurrent coarctation of the aorta in infancy. Am Surg 1959; 25: 908-11

66. Khoury GH, Hawes CR. Recurrent coarctation of the aorta in infancy and childhood. J Pediatrics 1968; 72: 801-6.

67. Ibarra-Pérez C, Castañeda AR, Varco RL, Lillehei CW. Recoarctation of the aorta Nineteen year clinical experience. Am J Cardiol 1969; 23: 778-84.

68. Parsons CG, Astley R. Recurrence of aortic coarctation after operation in childhood. Br Med J 1966; 1: 573-7.

69. Lezo JS, Pan M, Romero M, et al. Ballooon-expandable stent repair of severe coarctation of aorta. Am Heart J 1995; 129: 1002-8.

70. Ebeid MR, Prieto LR, Latson LA. Use of balloon-expandable stents for coarctation of the aorta: initial results and intermediate-term follow-up. J Am Coll Cardiol 1997; 30: 1847-52.
71. Amaral FTV, Granzotti JA, Nunes MA, Somerville J. Qualidade de vida após correção cirúrgica de coarctação da aorta: análise retrospectiva de um grupo de pacientes seguidos a longo prazo. Arq Bras Cardiol 1997; 68: 421-7.

72. Bergdahl L, Björk VO, Jonasson R. Surgical correction of coarctation of the aorta. Influence of age on late results. J Thorac Cardiovasc Surg 1983; 85: 532-6.

73. Simsolo R, Grunfeld B, Gimenez M, et al. Long-term systemic hypertension in children after successful repair of coarctation of the aorta. Am Heart J 1988; 115 : 1268-73

74. D'Abreu AL, Parsons C. Surgical treatment of children with coarctation of the aorta. BrMed J 1956; 2: 390-3.

75. Gidding SS, Rocchini AP, Moorehead C, Schork MA, Rosenthal A. Increased forearm vascular reactivity in patients with hypertension after repair of coarctation. Circulation 1985; 71: 495-9.

76. Ross RD, Clapp SK, Gunther S, et al. Augmented norepinephrine and renin output in response to maximal exercise in hypertensive coarctectomy patients. Am Heart J 1992; 123: 1293-9.

77. Gardiner HM, Celermajer DS, Sorensen KE, et al. Arterial reactivity is significantly impaired in normotensive young adults after successful repair of aortic coarctation in childhood. Circulation 1994; 89: 1745-50.

78. Ong CM, Canter CE, Gutierrez FR, Sekarski DR, Goldring DR. Increased stiffness and persistent narrowing of the aorta after successful repair of coarctation of the aorta: relationship to left ventricular mass and blood pressure at rest and with exercise. Am Heart J 1992; 123: 1594-600.

79. Xu J, Shiota T, Omoto R, et al. Intravascular ultrasound assessment of regional aortic wall stiffness, distensibility, and compliance in patients with coarctation of the aorta. Am Heart J 1997; 134: 93-8.

80. Clarkson PM, Brant PT, Barratt-Boyes BG, Rutherford JD, Kerr AR, Neutze JM. Prosthetic repair of coarctation of the aorta with particular reference to Dacron onlay patch grafts and late aneurysm formation. Am J Cardiol 1985; 56: 342-6.

81. Bromberg BI, Beekman RH, Rocchini AP, et al. Aortic aneurysm after patch aortoplasty repair of coarctation: a prospective analysis of prevalence, screening tests and risks. J Am Coll Cardiol 1989; 14: 734-41.

82. Knyshov GV, Sitar LL, Glagola MD, Atamanyuk MY. Aortic aneurysms at the site of the repair of coarctation of the aorta: a review of 48 patients. Ann Thorac Surg 1996; 61: 935-9.

83. Martin MM, Beekman RH, Rocchini AP, Crowley DC, Rosenthal A. Aortic aneurysms after subclavian angioplasty repair of aortic coarctation of the aorta. Am J Cardiol 1988; 61: 951-3

84. Graham TP, Atwood GF, Boerth RC, Boucek RJ, Smith CW. Right and left heart size and function in infants with symptomatic coarctation. Circulation 1977; 56: 641-6.

85. Krogmann ON, Kramer HH, Rammos S, Heusch A, Bourgeois M. Non-invasive evaluation of left ventricular systolic function late after coarctation repair: influence of early vs late surgery. Eur Heart J 1993; 14: 764-9.

86. Carpenter MA, Dammann JF, Watson DD, Jnedeiki R, Tompkins DG, Beller GA. Left ventricular hyperkinesia at rest and during exercise in normotensive patients 2 to 27 years after coarctation repair. J Am Coll Cardiol 1985; 6: 879-86.

87. Moskowitz WB, Schieken RM, Mosteller M, Bossano R. Altered systolic and diastolic function in children after "successful" repair of coarctation of the aorta. Am Heart J 1990; 120: 103-9.

88. Johnson MC, Gutierrez FR, Sekarski DR, Ong C, Canter CE. Comparison of ventricular mass and function in early versus late repair of coarctation of the aorta. Am J Cardiol 1994; 73: 698-701.

89. Leandro J, Smallhorn J.F, Benson L, et al. Ambulatory blood pressure monitoring and left ventricular mass and function after successful surgical repair of coarctation of the aorta. J Am Coll Cardiol 1992; 20: 197-204. 